\title{
Evaluating Congressional Constitutional Interpretation: Some Criteria and Two Informal Case Studies
}

\section{Citation}

Mark Tushnet, Evaluating Congressional Constitutional Interpretation: Some Criteria and Two Informal Case Studies, 50 Duke L.J. 1395 (2001).

\section{Published Version}

http://scholarship.law.duke.edu/dlj/vol50/iss5/6/

\section{Permanent link}

http://nrs.harvard.edu/urn-3:HUL.InstRepos:13751192

\section{Terms of Use}

This article was downloaded from Harvard University's DASH repository, and is made available under the terms and conditions applicable to Other Posted Material, as set forth at http:// nrs.harvard.edu/urn-3:HUL.InstRepos:dash.current.terms-of-use\#LAA

\section{Share Your Story}

The Harvard community has made this article openly available. Please share how this access benefits you. Submit a story.

Accessibility 


\title{
EVALUATING CONGRESSIONAL CONSTITUTIONAL INTERPRETATION: SOME CRITERIA AND TWO INFORMAL CASE STUDIES
}

\author{
MARK TUSHNET $\dagger$
}

Students of constitutional law regularly evaluate the Supreme Court's performance in interpreting the Constitution. Evaluations of Congress's performance of this same task are much less common. When we evaluate the Court's performance, our comments are frequently critical. That is, we do not believe that the Court's practice of interpretation of the Constitution is flawless. Yet, comments on Congress's performance frequently are based on the assumption that flaws in that institution's performance demonstrate its general inability to do a decent job of interpreting the Constitution.

We also have developed a number of justifications for judicial review. Assertions that the Court has some institutional superiority in deciding constitutional questions are common in those justifications. Those assertions might support a general skepticism about Congress's ability to interpret the Constitution well. Ordinarily, however, the claims about institutional superiority deal solely with structural characteristics of the Court and legislatures. So, for example, we note that electoral pressures may unduly influence members of Congress, ${ }^{1}$ even if they are sincerely interested in interpreting the Constitution correctly. ${ }^{2}$ In contrast, we point out, judges do not face such pressures.

Copyright (C) 2001 by Mark Tushnet.

$\dagger$ Carmack Waterhouse Professor of Constitutional Law, Georgetown University Law Center. I would like to thank Louis Michael Seidman for his comments on a draft of this Essay, Richard Friedman for his comments on Part II.B, and Jacqueline Shapiro for her research assistance.

1. Throughout this Essay, I use the term member of Congress to refer to representatives and senators.

2. For reasons that escape me, some people also assume that members of Congress invoke the Constitution only instrumentally-using the Constitution to support positions derived from some other agenda the members of Congress have-whereas they assume that courts act solely 
Further, members of Congress operate under severe time constraints as the nation's urgent business calls on them for decision. In the rush to determine national policy, conscientious deliberation over constitutional matters will be rare.

These observations about the comparative advantages of institutional structures are often correct. Yet incentives and institutional characteristics only conduce to behavior; they do not determine it. Identifying the actual effects of incentives and structure on behavior is fundamentally an empirical question. And yet, constitutional scholars rarely examine Congress's performance when it takes on the task of interpreting the Constitution.

In part, our neglect of the empirical dimension of the comparative inquiry results from our specialized training. Examining the actual operation of Congress would require us to consult sources with which we are less familiar than we are with the United States Reports: congressional hearings, floor debates, negotiations over legislative proposals, and more. In part, too, figuring out what evidence is relevant to a determination of the right answers to these empirical questions is quite difficult.

I begin this Essay by identifying some problems with conducting an empirical inquiry into Congress's performance in constitutional matters. I argue that there is actually only a small set of issues for which we have a reasonably clean record to evaluate. With the problems I have identified in the background, I then examine some aspects of Congress's performance in the impeachment of President William J. Clinton and, more briefly, some aspects of its response to a presidential military initiative taken without formal prior congressional endorsement. I conclude that Congress's performance in the impeachment, however flawed, was reasonably good, and that its performance in the war-powers context may have larger flaws but be reasonably good even so. ${ }^{4}$ Relative to the Supreme Court's imperfect

to implement their non-instrumentally held constitutional views. The skepticism that greeted the Supreme Court's decision in Bush v. Gore, 121 S. Ct. 525 (2000), suggests that the claimed differences are not thought to exist in every case.

3. For a brief, critical summary of conventional arguments about the institutional differences between legislatures and courts, see KeITH E. WhitTington, CONSTITUTIONAL Interpretation: TeXtual MEANing, ORIGinal InTENT, AND Judicial REVIEW 38-39 (1999).

4. Of course, in the end one needs to evaluate congressional performance-and judicial performance-across the entire range of action. My informal case studies are designed to give some credibility to the claim that Congress generally acts in a constitutionally responsible manner, but case studies cannot establish that claim. 
performance, the defects of Congress's performance may then seem less consequential, and the case for judicial review based on comparative demonstrated institutional competence may seem weaker.

\section{How to Evaluate CONGRESs's PERFORMANCE IN INTERPRETING THE CONSTITUTION}

Discussions of Congress's performance in interpreting the Constitution can easily get off track unless we take great care to ensure that we examine only cases offering a fair chance for sensible evaluation. This part offers some criteria for selecting such cases.

\section{A. Examine Institutional Performance, Not Individual Behavior}

It is trivially easy to compile a list of the constitutionally irresponsible or thoughtless proposals that members of Congress make. A member will shoot out a press release responding to some local outrage or put a bill in the hopper without taking any time to consider its constitutionality. ${ }^{5}$ Often these proposals result from the member's desire to grandstand, to do something that gets his or her name on the nightly news in the member's home district. ${ }^{6}$ They are not serious

5. For example, two days after Democratic presidential candidate Al Gore fumbled a question about whether he favored the execution of pregnant women (hardly a pressing matter of public policy), Representative Ileana Ros-Lehtinen, Republican of Florida, submitted a bill that would, if enacted, bar the execution of such women. The House approved the bill a week later. Innocent Child Protection Act, H.R. 4888, 106th Cong. (2000); GOP House Passes "Innocent Child" Bill, Chattanooga Times, July 26, 2000, at A6. The constitutional basis for such a statute is at least controversial. Under City of Boerne v. Flores, 521 U.S. 507 (1997), Section 5 of the Fourteenth Amendment grants Congress enforcement power if Congress can show that state governments have violated Fourteenth Amendment rights to a significant degree. Id. at 520 ("There must be a congruence and proportionality between the injury to be prevented or remedied and the means adopted to that end."). Assuming that executing a pregnant woman would be a constitutional violation, no state has done so, and the predicate for an exercise of the Section 5 power is absent. The bill might fall under the treaty power because the International Covenant on Civil and Political Rights, to which the United States is a signatory, prohibits the execution of pregnant women. International Covenant on Civil and Political Rights, Dec. 16, 1966, art. 6(5), 999 U.N.T.S. 171, 175. The United States reserved the right to execute persons who committed capital offenses when they were under the age of eighteen but did not reserve such a right with respect to pregnant women. Marian Nash, Contemporary Practice of the United States Relating to International Law, 89 AM. J. INT’L L. 96, 109 (1995). Recent revisionist scholarship has raised the question, though, of whether the treaty power is an independent source of congressional power. See generally Curtis A. Bradley, The Treaty Power and American Federalism, 97 MicH. L. REV. 390 (1998) (examining the relationship between the treaty power and American federalism) .

6. The behavior is related to what political scientists have called credit-claiming actions by members of Congress. DAvid MAYhew, Congress: The Electoral ConNection 52-53 (1974) (defining credit-claiming as "acting so as to generate a belief in a relevant political actor 
proposals for legislation, and the member has no real expectation that they would be enacted.

Noting grandstanding actions of this sort provides no basis for evaluating Congress's behavior. What we need to examine are institutional actions, those that represent the outcome of a completed congressional process. Institutional actions can, of course, consist of inaction as well. ${ }^{7}$ Grandstanding proposals may count against assertions that members of Congress act in a constitutionally responsible manner, but the failure of such proposals to move through the legislative process should count in favor of such assertions. Institutional actions have proceeded through a complex set of organizational structures. Those structures, designed for other purposes, may sometimes serve (imperfectly and as a by-product) to screen out constitutionally irresponsible actions. ${ }^{8}$

Examining institutional actions, however, raises its own difficulties. Judges write opinions when they decide what the Constitution means. Congress does not. Enacted statutes typically become effective without an accompanying statement of the constitutional rationale on which Congress relied. ${ }^{9}$ Determining the constitutional basis

(or actors) that one is personally responsible for causing the government, or some unit thereof, to do something that the actor (or actors) considers desirable").

7. Completed actions typically take two forms: enacted legislation (legislation passed by both the House of Representatives and the Senate, including, for these purposes, that legislation then vetoed by the President) and the rejection of proposals by a single house. Sometimes, however, a single house can affirmatively act. Examples include finding that a person has committed contempt of one house, which both the House and the Senate may do, and impeaching an officer of the United States, which is a completed action by the House of Representatives acting alone.

8. Congress's failure to adopt constitutionally mandated policies is another matter. There are, I believe, rather few such mandated policies in the sense that all reasonable constitutional positions converge on requiring the adoption of some such policy. (The closest I can come to an example is a requirement that legislatures provide adequate counsel to criminal defendants who lack personal resources to hire such counsel.)

9. One can design institutional mechanisms for supplying such rationales. For example, a "Committee on the Constitution" in each house could be given responsibility for preparing an authoritative statement on the constitutionality of every statute (or for stating that the Committee could come to no conclusion on constitutionality). Whether such mechanisms would counter the political processes that lead people to agree on specific proposals without agreeing on their constitutional rationales, and, perhaps more importantly, would overcome the pressure that time places on legislators who need to do something, seems to me quite questionable. The Senate's procedural rules provide that a point of order may be raised when a proposal raises a question of constitutionality. Floyd M. Riddick, Senate Procedure: Precedents and PrACTICES, S. DOC. No. 2-97, at 538-39 (1981). That procedure has been used rarely, however. For a discussion, see Louis Fisher, Constitutional Interpretation by Members of Congress, 63 
for a completed action by Congress requires us to examine a range of materials, such as committee reports, floor debate, and even newspaper stories, from which we can infer the constitutional basis on which Congress acted. ${ }^{10}$ Such inferences will inevitably be open to question. The evaluation of Congress's performance that results from such inferences will therefore often rest on a shaky foundation. Still, one should do the best one can. ${ }^{11}$

In addition, members of Congress often might have varying rationales for their belief that a proposal is constitutional. Unlike judges, they need not sign an opinion giving a majority's position on the constitutional question. ${ }^{12}$ Ultimately, each member of Congress must do no more than vote for the bill. But sometimes one constitutional rationale might be a good one and another bad. ${ }^{13}$ Imagine a statute adopted by a vote of 80-20. Sixty members of the majority thought about the constitutional questions the statute raised, and thought the statute justified by a rationale that, on detached reflection, one concludes was mistaken. But twenty members of the majority had a constitutionally good rationale for their votes. Without taking a position on the question, I simply observe that one reasonably could either challenge or defend the institutional action under these circumstances.

N.C. L. REV. 707, 719-21 (1985) (discussing use of a point of order in opposition to an amendment giving the President item-veto authority over appropriations bills).

10. For an example of this sort of analysis, see infra Part II.C (discussing the House of Representatives' decision on the burden of proof necessary to support a vote in favor of impeachment).

11. Although this Essay deals only with congressional constitutional performance, I think it worth noting an additional difficulty, associated with the need to examine only completed actions, when we try to evaluate the constitutional performance of state and local officials. I believe that the proper subject of evaluation in that context is, again, completed actions, but in the state and local context an action should not be regarded as completed unless it is authorized by-and perhaps survives challenges under-state law. My concern is with legislative adherence to the national Constitution. Determining whether a local ordinance is compatible with state nonconstitutional law, or whether it or a state statute is compatible with state constitutional law, raises a different set of questions. For example, the judicial overhang with respect to a state constitution might be quite small if the state constitution is easier to amend than is the national Constitution.

12. I leave aside here the fact that the Supreme Court sometimes issues opinions in which only a plurality of the Justices accept a single rationale.

13. For example, Representative Ros-Lehtinen's proposal, supra note 5, might be constitutionally justified by the treaty power but not by the Section 5 power. 


\section{B. Examine Institutional Actions Outside the Shadow Cast by the Courts}

The existence of judicial review itself poses a problem for those who would evaluate congressional constitutional performance. Most analysts think that anticipatory obedience to the courts is desirable. ${ }^{14}$ A legislature engages in anticipatory obedience when it predicts what a court would say about a proposal's constitutionality were the measure to be enacted and adapts the proposal to ensure that it will survive judicial scrutiny.

I have argued elsewhere that anticipatory obedience may sometimes distort enacted statutes. ${ }^{15}$ Judicial review presents another problem for those who would evaluate Congress's constitutional performance, however. I have called this the problem of the judicial overhang. ${ }^{16}$ Judicial review provides an opportunity for Congress as a body, not just individual legislators, to engage in grandstanding by enacting statutes that members of Congress can be confident will be held unconstitutional. Consider a situation in which members of Congress have a choice: they can enact a splashy statute that directly attacks a problem, albeit in a way that the courts will find unconstitutional, or they can enact a boring one, full of obscure details, that might be a bit less effective in achieving the majority's policy goals but that would be unquestionably constitutional. Presumably, enacting a statute that advances policy goals is attractive politically but sometimes enacting the splashy, but unconstitutional, statute may be even more politically attractive. ${ }^{17}$ Members then can take credit for trying to do something and blame the courts for the failure, even though the other statute might have been both constitutional and nearly as effective in achieving Congress's policy goals. ${ }^{18}$

14. I draw the term anticipatory obedience from Jutta Limbach, The Role of the Federal Constitutional Court, 53 SMU L. REV. 429, 433 (2000).

15. Mark Tushnet, TAKing the Constitution AwAy From the Courts 58-60 (1999)

16. Id. at 57.

17. Sometimes, I suppose, members of Congress might not have policy goals in mind but simply want to get on the nightly news by enacting a statute. Here, the prospect of judicial review may induce even worse performance by Congress.

18. I believe that the Communications Decency Act, held unconstitutional in Reno $v$. $A C L U, 521$ U.S. 844 (1997), is an example of congressional grandstanding through enactment of a statute certain to be held unconstitutional. 
This behavior, which we might call anticipatory disobedience, is pretty clearly undesirable. ${ }^{19}$ Even if rather common, though, anticipatory disobedience might shed little light on the question of congressional constitutional capacity. People will overeat if someone gives them free candy, but that fact says little about their actual desires regarding nutrition. To determine those desires, one would have to take people away from the setting in which they have access to free candy. Analogously, we can get a better sense of Congress's actual constitutional capacity if we examine only cases in which Congress cannot engage in anticipatory disobedience. The fact that members of Congress behave badly when they know that someone is around to bail them out tells us little about how they would behave were they to have full responsibility for their actions. Such cases do exist: cases in which there is no realistic prospect of judicial review, so that members of Congress know that they have full and exclusive responsibility for arriving at a conclusion that, according to their oaths of office, must be consistent with the Constitution.

\section{Avoid Examining Problems Where People Can Reasonably Disagree About the Constitution's Meaning}

One of the most serious pitfalls in evaluating congressional constitutional performance occurs when an analyst sets up a standard and asks whether Congress's action conforms to the standard, when others might reasonably set up a quite different standard. The posited standard may be the analyst's own conclusion about the Constitution's proper meaning or it may be a standard drawn from Supreme Court decisions. Divergence from the standard nonetheless may tell us almost nothing about Congress's constitutional performance.

Take for example the problem of campaign finance and the First Amendment. Suppose we take the Supreme Court's decision in Buckley v. Valeo ${ }^{20}$ as the standard by which we measure Congress's constitutional performance. Undoubtedly many existing proposals for campaign finance reform are inconsistent with the doctrine laid out in Buckley. Assume that supporters of such proposals do not really ex-

19. Anticipatory disobedience is undesirable except to the extent that it may be valuable as a vehicle allowing representatives to blow off steam before they get down to the serious business of legislating.

20. 424 U.S. 1 (1976) (upholding provisions of the Federal Election Campaign Act, which limits individual campaign contributions, but striking down Act provisions limiting candidates' personal expenditures as unconstitutional under the First Amendment). 
pect that the Supreme Court will soon overrule Buckley. ${ }^{21}$ It seems to me quite wrong to say that these supporters are behaving in a constitutionally irresponsible manner. After all, many respected constitutional scholars, and even some Supreme Court Justices, believe that Buckley was wrongly decided..$^{22}$ As long as the constitutional position asserted by Congress is a reasonable one, Congress can act responsibly, in constitutional terms, even when it enacts statutes that the Court eventually holds unconstitutional. So simply listing the statutes the Supreme Court has held unconstitutional does not give us any real measure of Congress's constitutional performance.

This problem arises even outside the context of judicial review. Consider here the furious debate over whether President Clinton had committed an impeachable offense. The constitutional language was clear, but its meaning was not. Relying on their interpretation of the original understanding of the term high Crimes and Misdemeanors, some argued that a President could be impeached only for actions taken in his official capacity that posed a serious threat to the nation's political integrity. ${ }^{23}$ Relying on a different interpretation of the original understanding and on some obvious functional considerations,

21. The assumption is necessary only because some people may support proposals that are inconsistent with Buckley as a means of provoking the Court into reconsidering that case. Those who want the Court to reconsider Buckley accept the Court as the authoritative expositor of the Constitution; the members of Congress described in the text need not make that assumption.

22. E.g., Owen M. Fiss, Money and Politics, 97 ColuM. L. REv. 2470, 2470 (1997) (arguing that the Buckley Court inappropriately ignored the First Amendment principle of preservation of public debate and imposed a barrier against the most effective means of limiting money's negative impact on the political process, namely, mandatory public election campaign financing); Burt Neuborne, The Supreme Court and Free Speech: Love and a Question, 42 ST. LouIS U. L.J. 789, 795-96 (1998) (arguing that, "[e]mbedded in the [Buckley] opinion are three mistakes that ... deal an inadvertent body blow to democracy"); Ronald Dworkin, The Curse of American Politics, N.Y. REV. OF BooKs, Oct. 17, 1996, at 19 (arguing that Buckley should be reversed because it was based on a misunderstanding of the fundamental premises of the First Amendment as well as American democracy); see also Nixon v. Shrink Mo. Gov't PAC, 528 U.S. 377, 406 (2000) (Kennedy, J., dissenting) (stating that the Court's decision in Shrink "perpetuates and compounds a serious distortion of the First Amendment resulting from our own intervention in Buckley"); FEC v. Nat'l Conservative PAC, 470 U.S. 480, 507-08 (1985) (White, J., dissenting) (stating that "I continue to believe that Buckley v. Valeo was wrongly decided" because governmental interests, such as "the need to avoid real or apparent corruption," justify restriction on the amassing and spending of money in political campaigns); id. at 519 (Marshall, J., dissenting) (stating that, "[a]lthough I joined the portion of the Buckley per curiam that distinguished contributions from independent expenditures for First Amendment purposes, I now believe that the distinction has no constitutional significance").

23. For a discussion of the competing interpretations of the constitutional term, see Richard A. Posner, An Affair of State: The Investigation, Impeachment, and TRIAL OF PRESIDENT CLINTON 98-99 (1999). 
others gave the example of a President who commits a murder for nonpolitical reasons and insisted that a President could be impeached for actions taken in their personal capacity, when such actions cast grave doubt on the President's personal integrity and on his ability to continue to represent the nation's people. ${ }^{24}$

The House voted to impeach the President, adopting a theory more like the second than the first. ${ }^{25}$ The second theory may be wrong, but it is clearly a reasonable one: the standard is consistent with the Constitution's language, it makes functional sense, and it is consistent with at least some aspects of Congress's past practices in impeachment. ${ }^{26}$ It seems clear to me that opponents of the Clinton impeachment have no real ground for saying that the House acted in a constitutionally irresponsible manner in adopting the second theory; ${ }^{27}$ I simply note my puzzlement about concern that the House did not "adopt" a definition of impeachable offenses. ${ }^{28}$ I find it hard to

24. Cass R. Sunstein, Impeachment and Stability, 67 GEO. WASH. L. REV. 699, 709 (1999) ("[A] President would be impeachable for an extremely heinous 'private' crime, such as murder or rape."); see also Frank O. Bowman, III \& Stephen L. Sepinuck, "High Crimes and Misdemeanors": Defining the Constitutional Limits on Presidential Impeachment, 72 S. CAL. L. REV. 1517, 1545 (1999) ("Criminal sexual misbehavior such as rape ... would surely be an impeachable offense."); Charles J. Cooper, A Perjurer in the White House?: The Constitutional Case for Perjury and Obstruction of Justice as High Crimes and Misdemeanors, 22 HARV. J.L. \& PUB. POL'Y 619, 620-21 (1999) ("[T]he crimes of perjury and obstruction of justice, like the crimes of treason and bribery, are quintessentially offenses against our system of government, visiting injury immediately on society itself whether or not committed in connection with the exercise of official government powers.").

25. In saying that the House "adopted" a theory, I am aware of the problem of inference from behavior only, discussed supra in Part I.A.

26. The House Judiciary Committee refused to vote an article of impeachment against President Richard Nixon based on irregularities in his preparation of a tax return. For a discussion, see Laurence H. Tribe, Defining "High Crimes and Misdemeanors": Basic Principles, 67 GEO. WASH. L. REV. 712, 721 (1999). The House did impeach Walter Nixon, former Chief Judge of the United States District Court for the Southern District of Mississippi, for actions taken at least arguably outside his official capacity, in connection with false testimony to a federal grand jury about telephone calls he made to a state prosecutor in exchange for payment. Nixon v. United States, 506 U.S. 224, 226-28 (1993).

27. As discussed in a related context infra in Part II.C, perhaps one can criticize the House of Representatives for failing to conduct a focused discussion of the definition of impeachable offenses until relatively late in the proceedings. A hearing exploring the question took place before a subcommittee of the House Judiciary Committee on November 9, 1998. See generally Background and History of Impeachment: Hearing Before the Subcomm. on the Constitution of the House Comm. on the Judiciary, 105th Cong. 230 (1998) (reporting the prepared statements of nineteen constitutional experts).

28. See, e.g., Susan Low Bloch, A Report Card on the Impeachment: Judging the Institutions that Judged President Clinton, 63 LAW \& CONTEMP. ProBs. 143, 150 n.37 (Winter/Spring 2000) ("Unfortunately, neither the full Judiciary Committee nor the House as a whole ever ar- 
understand what the effect would be of a standard adopted by a majority vote in the House, prior to the vote on impeachment itself, on a House member who voted against the standard, even if that member believes that the first theory is the constitutionally mandated one. ${ }^{29}$

The more general point is that many constitutional questions admit of reasonable disagreement and that all sides in a dispute can take different positions while all remain faithful to the Constitution. Take the problem in a different setting. The Supreme Court issues a constitutional decision. I may think that the Constitution pretty clearly means something else, and indeed three Supreme Court Justices agree with me. I doubt that anyone could fairly charge me with being faithless to the Constitution were I to persist in holding the view I held before the Court acted.

Now, take the problem in the setting with which this Essay is concerned: Congress acts in a way inconsistent with some stipulated standard, whether it be the critic's or the Supreme Court's. The mere fact that Congress disagrees with the Supreme Court or with the critic does not establish that Congress behaved in a manner that demonstrates its inability to arrive at reasonable conclusions about the Constitution. My impression is that people find it psychologically difficult to hold the following two views at the same time: first, a firm belief that the constitutional interpretation they have arrived at by sound legal reasoning is correct; and second, an acknowledgment that reasonable people using the same methods of legal reasoning could arrive at a different conclusion. Yet the persistence of real and goodfaith disagreement about what the Constitution means implies that both of those views, or something like them, must be correct.

Thus, Congress may be wrong, from my point of view or from that of the Supreme Court. Its "errors" do not, however, show that Congress is performing badly as a constitutional decisionmaker. At most, these "errors" show that Congress disagrees with me, or the Supreme Court, about what the Constitution means. Evaluations of congressional constitutional performance must therefore take account of the fact of reasonable disagreement over the Constitution's meaning. The criterion an evaluator must apply is this: Did Congress do something that is outside the range of reasonable interpretations of

ticulated or agreed on a general standard.").

29. At this point I am making no observation about whether President Clinton's behavior actually was inconsistent with the standard defined by this second theory. My concern is only with the adoption of the theory as the basis upon which to evaluate his behavior. 
the Constitution $?^{30}$ Obviously this criterion tilts the field of evaluation in Congress's favor-setting a baseline that is truly a line rather than a point-because of the fairly wide range of reasonable positions available on nearly every constitutional question. ${ }^{31}$ But, to me, it is the only criterion that makes sense.

\section{Examine Only Cases Where the Constitution Provides Answers}

Broadly described, the Constitution creates a political structure and prescribes some particular outcomes. Across a wide range, the Constitution says nothing about the outcomes that people operating within its structures must reach. To make the point obvious, the Constitution says nothing about whether the highest marginal rate should be $26 \%, 39 \%$, or $54 \%$ in the income-tax system, even if there is a constitutional requirement that tax rates not be confiscatory, ${ }^{32}$ or whether there should be a time limit on eligibility for federally provided public assistance, even if there is some constitutional requirement that legislatures provide minimum subsistence for the needy. Clearly one cannot evaluate the degree to which congressional action conforms to the Constitution when the Constitution gives Congress unfettered discretion to act.

30. The evaluator must therefore be careful to ensure that he or she not unfairly label as "unreasonable" a constitutional position with which he or she disagrees. So, for example, while I believe that impeachment's opponents had the better case on what the standard for impeachment is, I believe as well that impeachment's supporters offered a reasonable, albeit erroneous, standard. See supra notes 23-29 and accompanying text.

31. This is not to say that the criterion guarantees that we always will find that Congress acted in a constitutionally responsible manner. The problem that bedevils me is the federal statute banning flag-burning held unconstitutional in United States v. Eichman, 496 U.S. 310 (1990). I cannot think of a reasonable theory of free expression according to which that statute was constitutional. Indeed, as I read the dissent in that case, the dissenters agreed that the statute was unconstitutional under generally applicable free expression principles. Id. at 322-24 (Stevens, J., dissenting). They argued that the case of flag-burning called for making an exception to such principles. Id. (Stevens, J., dissenting). I agree that such exceptions are sometimes appropriate, and I go back and forth in my mind on the question of whether it is reasonable to make an exception for that case.

32. In E. Enters. v. Apfel, 524 U.S. 498 (1998), four Justices rejected the proposition that a tax scheme could never be an unconstitutional taking. Id. at 522 (O'Connor, J., writing for a plurality of herself and Justices Rehnquist, Thomas and Scalia); id. at 538 (Thomas, J., concurring) (agreeing with the plurality that the statute at issue violates the Takings Clause). But Justice Kennedy wrote for four other Jusitices in warning that takings analysis should not be applied where a specific property right has not been destroyed. Id. at 541-42 (Kennedy, J., concurring in the judgment and dissenting in part); $i d$. at 554 (Breyer, J., dissenting, joined by Souter and Ginsburg, JJ.) (agreeing with Justice Kennedy that "the plurality views this case through the wrong legal lens"; the Takings Clause does not apply). 
The income-tax and welfare-reform examples raise what we usually think of as ordinary policy questions. According to some respectable constitutional theories, some constitutional issues have the same analytic structure. According to these theories, the Constitution establishes a structure giving participants incentives to respond to constitutional questions in position-specific ways and treats as constitutionally valid the outcome of the political process that operates according to those incentives. Herbert Wechsler's account of federalism is one example of such a theory. ${ }^{33}$ According to Wechsler, the Constitution's structures gave political actors incentives to assert varying positions about the proper distribution of power between the national government and state governments. Whatever accommodation the political actors reached was what the Constitution meant. ${ }^{34}$ Jesse Choper offered a similar theory of separation of powers. ${ }^{35}$ The Constitution gave members of Congress and the President political interests that would be served by preserving the power of their respective institutions, setting the institutions and their members at political odds over the distribution of power within the national government. The President would seek to maximize his or her power over officials within the national government, for example, while members of Congress would try to maximize their power over the very same officials. Political combat between Congress and the President will produce some outcome and, according to Choper, that outcome is what the separation of powers means. ${ }^{36}$

33. See generally Herbert Wechsler, The Political Safeguards of Federalism: The Role of the States in the Composition and Selection of the National Government, 54 COLUM. L. REV. 543, 546 (1954) (arguing that "the existence of the states as governmental entities and as sources of the standing law is in itself the prime determinant of our working federalism, coloring the nature and the scope of our national legislative processes from their inception").

34. Id. at 559-60. Obviously, such accommodations change over time, and so the Constitution's meaning changes. But this is not anomalous with respect to the constitutional provisions addressed by theories like Wechsler's.

35. See generally Jesse H. ChOPer, Judicial Review ANd the National Political Process: A Functional Reconsideration of the Role of the Supreme Court (1980). Choper's theory differs from Wechsler's in a subtle but important way. Choper argues that questions of federalism and the separation of powers should be nonjusticiable, meaning that the courts should not resolve them. One can agree with that argument while also believing that the Constitution does in fact supply an answer to the questions: Nonjusticiability means not that the Constitution defines the separation of powers questions as whatever allocation of power the political branches reach, but only that the courts will not specify the constitutionally required separation of powers.

36. Id. at 263 . 
The implication of such theories for evaluating congressional constitutional responsibility is clear: the concept of congressional constitutional responsibility is inapt with respect to provisions where the Constitution does no more than create a political structure and incentives for the occupants of different positions. The Constitution, according to theories of this sort, provides no standard whatever against which to assess congressional action.

Of course, the Constitution does specify standards for many of its provisions. Further, theories like Wechsler's and Choper's are of course quite controversial, rejected by the Supreme Court ${ }^{37}$ and by many constitutional scholars. ${ }^{38}$ The criterion that would allow us to select only cases outside the range of reasonable disagreement for evaluation suggests, however, that mere controversy is insufficient to disqualify a theory from the terrain. So, for example, a member of Congress who says openly that, as far as he or she is concerned, the Constitution places no limits on Congress's power to regulate state governments - a member, that is, who accepts Wechsler's theory-is acting in a constitutionally responsible manner.

One limitation on the scope of this fourth criterion deserves special note. Few members of Congress will, in fact, assert that the Constitution places no substantive limits on what they may do. As a representative, Gerald Ford notoriously asserted that an impeachable offense "is whatever a majority of the House [considers it] to be at a given moment in history." 39 As far as I can tell, this position had no purchase whatever during the Clinton impeachment. Impeachment's proponents and opponents alike produced standards for determining whether the President's actions constituted an impeachable offense; no one said, at least in public, that Ford had been correct and that the House could impeach the President simply because a majority wanted to do so. I suspect that the reason for this restraint is that members of Congress know that their constituents believe that the Constitutionin all its provisions-means something, and that openly declaring that

37. See, e.g., United States v. Lopez, 514 U.S. 549, 578 (1995) (Kennedy, J., concurring) (referring to the absence of structural mechanisms to require members of Congress to consider the interests of states when they adopt legislation); INS v. Chadha, 462 U.S. 919, 942 n.13 (1983) (rejecting the proposition, implicit in Choper's approach, that "[ $t]$ he assent of the Executive to a bill which contains a provision contrary to the Constitution... shield[s] it from judicial review").

38. See, e.g., William P. Marshall, Federalization: A Critical Overview, 44 DePAUl L. REV. 719, 728-32 (1995) (concluding that "the political checks that do exist do not go very far in assuring that federalism concerns are adequately protected").

39. 116 Cong. ReC. H11, 913 (daily ed. Apr. 15, 1970) (statement of Rep. Ford)). 
$\mathrm{n}$ all its provisions-means something, and that openly declaring that a constitutional provision (or arrangement, like federalism and the separation of powers) has no substantive content would demonstrate constitutional irresponsibility to the constituents, even if there is some theory of constitutional responsibility under which such a declaration is reasonable.

Because our first criterion asks us to examine completed actions, not proposals, or even arguments, what members of Congress are willing to say may be irrelevant. We should at least try to examine constitutional controversies where the claim that the Constitution provides no substantive standard is outside the range of reasonableness.

\section{THREE EXAMPLES FROM THE CLINTON IMPEACHMENT}

Congress's actions during the Clinton impeachment offer an opportunity to assess Congress's constitutional performance for several reasons. First, there was a completed congressional process. Second, The Supreme Court's decision in Walter Nixon v. United States, ${ }^{40}$ holding that challenges to the procedures the Senate used to try Judge Nixon presented political questions, ${ }^{41}$ made it reasonably clear that no court would review any decision taken in the course of a presidential impeachment. ${ }^{42}$ As for my third criterion, as noted earlier, some important legal questions connected to impeachment have a wide range of reasonable answers, and there might be no legal standard available with respect to others. Still, some interesting legal questions about impeachment have answers within a sufficiently narrow range that we can assess how well Congress did in answering them. This part considers three such questions: whether a President could be impeached and convicted but not removed from office; whether the Senate can properly proceed when presented with an impeachment completed by the House of Representatives during one

\footnotetext{
40. 506 U.S. 224 (1993).

41. Id. at 226 .

42. Indeed, in Nixon the Court used the example of judicial review of a presidential impeachment to demonstrate why challenges in judicial impeachments were political questions. $I d$. at 236 ("[A] lack of finality [attendant upon judicial review] would manifest itself most dramatically if the President were impeached."). Still, Nixon only made it reasonably clear that there would be no judicial review, because some aspects of that decision suggest that the Court refused to review Judge Nixon's challenge only because the Justices concluded that Congress had adopted a constitutional interpretation that was, in the Justices' view, a reasonable one. E.g., id. at 230 (referring to the "variety of definitions" of the word "try").
} 
session but not renewed in the next session; and whether the House of Representatives can impeach a President simply by concluding that a grand-jury-like standard of probable cause has been satisfied.

\section{A. Impeachment and Conviction Without Removal}

The prospects for President Clinton's conviction and removal from office, never large, diminished as the impeachment process went on. Law professor Joseph Isenbergh suggested that the House and Senate could express their disapproval of the President's conduct by impeaching and convicting him but not removing him from office. ${ }^{43}$ Isenbergh's argument began with the text. According to Article II, the President "shall be removed from Office on Impeachment for, and Conviction of, Treason, Bribery, or other high Crimes and Misdemeanors." ${ }^{44}$ This is the Constitution's only reference to grounds for impeachment. As Isenbergh read the provision, it was "a mandatory sentencing provision": if a President is impeached for and convicted of a high crime or misdemeanor, then the President must be removed. But, according to Isenbergh, this provision did not rule out another scenario: the President could be impeached for and convicted of something other than a high crime or misdemeanor, in which case removal from office was not mandatory but rather discretionary. ${ }^{45}$ In addition, Isenbergh noted that the category of high crimes and misdemeanors was well understood at the Framing to refer to offenses against the state and that removal from office of a person who committed such offenses plainly was appropriate. ${ }^{46}$ But, according to Isenbergh, the Framers (probably) anticipated that an official might commit misconduct, like murder, unconnected to office and yet deserving of public sanction. Impeachment for and conviction of such an offense, coupled with a sanction other than removal, is an appropriate

43. The argument is set out in Joseph Isenbergh, Impeachment and Presidential Immunity from Judicial Process, 18 YALE L. \& POL'Y REV. 53 (1999).

44. U.S. CONST., art. II, § 4.

45. Isenbergh, supra note 43, at 64. Isenbergh found support for his proposal in Article I, Section 3, which provides that "Judgment in Cases of Impeachment shall not extend further than to removal from Office, and disqualification ...." Id. at 65 (citing U.S. CoNST. art. I, § 3 , cl. 7). This suggests that a person impeached and convicted might be subjected to a sanction less severe than removal from office, although the natural reading of the provision is that it rules out sanctions more severe than removal from office. Id. But, contrary to Isenbergh's proposal, the provision has no obvious implications for the question of whether a person could be impeached for, and convicted of, something other than a high crime or misdemeanor.

46. Id. at 67-69. 
response. ${ }^{47}$ Finally, Isenbergh suggested, this scenario made some functional sense, as the Clinton episode itself indicated. Presidents might engage in misconduct not severe enough to justify removal from office but sufficiently severe as to deserve the high degree of formal condemnation that impeachment and conviction would represent. ${ }^{48}$

Isenbergh's proposal received some endorsement in the press but got nowhere in Congress. ${ }^{49}$ The reasons are clear. First, and in my judgment, less important, the proposal did not actually serve the political interests of those supporting impeachment and conviction. As the impeachment wore on, it became clear that impeachment's proponents really did believe that the President should be removed from office and that any step short of removal was tantamount to approval of the President's conduct.

Second, and more important, Isenbergh's proposal, while not entirely insupportable, was wildly at odds with well-settled understandings about impeachment. ${ }^{50}$ As far as I know, no serious consideration had ever been given to the possibility that civil officers could be impeached for and convicted of something less than a high crime or misdemeanor. ${ }^{51}$ Isenbergh accurately noted that the Constitution's

47. Id. at 72-73 (citing Thomas Jefferson's understanding of the English precedent that impeachment "may proceed against the delinquent of whatsoever degree, and whatsoever be the nature of the offence").

48. Id. at 86 (asserting that censure was a more apposite resolution for milder misconduct). The former condition is required to establish that impeachment and conviction is functionally more appropriate than a concurrent resolution of censure.

49. For a discussion that reprints a series of exchanges over Isenbergh's proposal, see Akhil Reed Amar, On Impeaching Presidents, 28 Hofstra L. REV. 291, 317-41 (1999) (reprinting journalistic exchanges between Amar and Stuart Taylor, Jr., dealing with Isenbergh's proposal, among other topics). Taylor noted that "[n]ot one senator has warmed to" Isenbergh's proposal. $I d$. at 324. Senator Susan Collins, Republican of Maine, proposed a variant of Professor Isenbergh's proposal, in which the Senate would first vote on whether to find the President guilty of the impeachment charges and then on whether to remove him from office. See Lorraine Adams, A Freshman with an Endgame Idea; As Unassuming Advocate, Collins Hopes "Findings of Fact" Will Send Message, WASH. PosT, Jan. 29, 1999, at A1. For a discussion of this variant, see Michael J. Gerhardt, The Historical and Constitutional Significance of the Impeachment and Trial of President Clinton, 28 Hofstra L. REv. 349, 378-82 (1999). Notably, the major scholarly treatment of the Clinton impeachment barely mentions Isenbergh's proposal. See PosNER, supra note 23, at $98 \mathrm{n} .8$ (finding Isenbergh's position "arguable from the text and background of the impeachment clauses," but also "contrary to the modern understanding of these clauses"). Posner and Isenbergh are colleagues at the University of Chicago Law School.

50. Amar correctly uses the term "mainstream" to refer to the position against which Isenbergh was arguing. Amar, supra note 49, at 332,

51. Amar also asserts that Isenbergh could not point to a single Founder who expressed the Isenbergh view. $I d$. at 333 . 
text made this possibility available..$^{52}$ But text-and even modest functional sense-is not all that matters in constitutional interpretation. Practice and settled understandings matter as well. Here, practice and settled understandings were so firmly established that Isenbergh's proposal lay outside the bounds of reasonable interpretation. Nor did Isenbergh suggest why those settled understandings should be displaced in favor of an interpretation that, on his view, had always been available. ${ }^{53}$ Congress's inattention to the proposal demonstrated its ability to reject unreasonable constitutional interpretations. ${ }^{54}$

\section{B. “Lame Duck” Impeachments}

Another law professor weighed in with a similarly innovative proposal. According to Bruce Ackerman, a "lame duck" impeachment was constitutionally questionable..$^{55}$ A "lame duck" impeachment, in Ackerman's terms, was one in which the impeachment was voted by a House of Representatives that had convened for a session after an election but a newly elected Senate conducted the trial. Ackerman noted some functional concerns about lame-duck impeachments, particularly that some House members who might vote in favor of impeachment might have been rejected by their constituents, perhaps precisely because they found unacceptable a vote by their representative in favor of impeachment. ${ }^{56} \mathrm{He}$ also acknowledged that the precedents prior to the New Deal were strongly against him. British parliamentary practice, adopted in Thomas Jefferson's account of legislative procedures, treated an impeachment differently than ordinary legislation. Legislative proposals, even those adopted by a single house, expired when not enacted before a legislative session ended. Impeachments, in contrast, continued from one legislative session to another. ${ }^{57}$ Further, Ackerman agreed that pre-New Deal

52. Isenbergh, supra note 43, at 63 ("A close reading of the Constitution ... reveals that ... Congress has the power to impeach and remove civil officers for a range of offenses other than high crimes and misdemeanors ....").

53. This is in contrast with Bruce Ackerman's proposal, discussed infra in Part II.B, which did rely for support on post-1789 developments.

54. That is, the final action taken by Congress was its refusal to accept Isenbergh's proposal.

55. Bruce Ackerman, The Case Against Lameduck Impeachment 31 (1999).

56. Id. at 7-8 (discussing the change in the House's membership immediately following the vote to impeach President Clinton).

57. Id. at 49 (quoting Thomas Jefferson's notation that "impeachment is not discontinued by the dissolution of Parliament"). 
practice included several examples of impeachments that carried over from one congressional session to another. ${ }^{58}$

But, Ackerman argued, everything changed with the adoption of the Twentieth Amendment in 1933. According to Ackerman, the campaign for that Amendment's adoption centered on charges that actions taken by lame-duck Congresses lacked democratic legitimacy. ${ }^{59}$ The Amendment compressed the time between an election and the convening of a new Congress to eliminate, or at least reduce, the possibility that a Congress that had been electorally repudiated would take significant action. Of course, the possibility of a lameduck session remained open because the Amendment provided for a two-month period between the election and the new Congress's initial sitting. And Ackerman agreed that actions that were completed during a lame-duck session were constitutionally permissible. So, for example, an "old" Congress could still enact legislation and even (in theory) impeach and convict a President. ${ }^{60}$

On Ackerman's view, therefore, the House of Representatives could indeed impeach the President in a lame-duck session, because impeachment was an act that could be completed by the House alone. But, Ackerman argued, the newly convened Senate should not proceed to a trial "unless and until [the new House of Representatives] ... soberly and self-consciously reaffirm[ed]" that the President should be impeached. ${ }^{61}$

I believe that Ackerman's proposal received less serious consideration than it should have, in contrast to the appropriate lack of consideration given Isenbergh's proposal. Ackerman's argument had several large analytic problems, however. ${ }^{62}$ First, he agreed that lame-

58. Id. at 57-64 (describing pre-New Deal lame-duck impeachments).

59. Id. at 17 (describing the supporters of the lame-duck amendment as viewing the amendment as "part of the struggle for democracy"). Michael Stokes Paulsen therefore seems wrong in asserting that " $[\mathrm{t}] \mathrm{he}$ fact that the House's action occurred during a lame duck session is entirely incidental to Ackerman's claim." Michael Stokes Paulsen, I'm Even Smarter than Bruce Ackerman: Why the President Can Veto His Own Impeachment, 16 Const. Comment. 1, 2 (1999).

60. ACKERMAN, supra note 55, at 30 (refraining from a denial that the lame-duck 105th Congress had the constitutional power to vote to impeach before January 3 ).

61. Id. at 32. This quotation, and other parts of Ackerman's argument, should make it clear that Paulsen is mistaken in describing Ackerman's "premise" as being "that impeachment-andtrial is a single act and, therefore, like any other ordinary bill, must pass both the House and the Senate during the same Congress." Paulsen, supra note 59, at 2.

62. These criticisms of Ackerman's argument draw on, although they differ somewhat from, arguments made in notes generously made available to me by Professor Richard Friedman of the University of Michigan Law School. E-mail from Richard D. Friedman, Ralph W. 
duck Congresses could enact quite significant laws, even by majorities that had been repudiated in the election. ${ }^{63}$ The distinction Ackerman sought to draw between completed acts, including legislation and impeachments, and continuing ones, such as the trial of an impeachment charge already made, was quite thin. ${ }^{64}$ Second, the Twentieth Amendment shortened the time in which a lame-duck Congress could sit, but it did not eliminate the possibility of lame-duck sessions. Ackerman therefore had to rely on what might be disparaged as the "invisible radiation[s] ${ }^{165}$ of the Amendment to cast doubt on the legitimacy of a trial based on an impeachment voted by a lame-duck House of Representatives. That is, the Amendment did not address the constitutionality of any action taken during or after the lame-duck sessions that it clearly permitted, yet, on Ackerman's view, the Amendment's general policy should be taken into account in developing the law of impeachment. One might reasonably ask for more than this as the basis for repudiating clear pre-1933 precedent.

These problems are perhaps sufficient to render Ackerman's argument unacceptable, but the Senate should have thought through Ackerman's proposal before rejecting it. ${ }^{66}$ Why did it not? Again, politics played a role. Even on Ackerman's view, the real question was whether the Senate should proceed with a trial. By the time the Senate had to act, however, it was clear to most observers that a trial would not result in conviction. Terminating proceedings in the ordinary way probably seemed cleaner to Senators than doing so by adopting a novel theory of the law of impeachment.

Aigler Professor of Law, University of Michigan Law School, to Mark V. Tushnet, Carmack Waterhouse Professor of Constitutional Law, Georgetown University Law Center (Nov. 21, 2000) (on file with the Duke Law Journal).

63. For example, the statute approving United States participation in the World Trade Organization was adopted by a lame-duck Congress; notably, that Congress had a Democratic majority while its successor would have a Republican one. The Comprehensive Environmental Response, Compensation, and Liability Act of 1980 also was enacted by a lame-duck Congress. Exxon Corp. v. Hunt, 475 U.S. 355, 379 n.5 (1986) (Stevens, J., dissenting).

64. Part II.C discusses questions that arose when members of Congress thought of the House of Representatives as a grand jury and the Senate as a trial jury. On that conceptualization of the impeachment process, it is hard to see why the trial jury cannot accept an "indictment" made by a grand jury whose term has expired.

65. Missouri v. Holland, 252 U.S. 416, 434 (1920) (deciding whether a treaty was forbidden by an "invisible radiation" of the Tenth Amendment).

66. I note that the newly elected House of Representatives did reappoint managers for the impeachment. As a formal matter that was the ratification or adoption of the articles of impeachment by the new House, but, because the managers were reappointed in a largely pro forma manner, I do not think that the reappointment standing alone would satisfy Ackerman's concerns. 
In addition, Ackerman's argument was complex and, in my view, somewhat muddled at a crucial point. Understood correctly, Ackerman was urging that the Senate ought to insist on a vote on impeachment by the newly elected House of Representatives. The imperative here should be understood, I believe, as arising from concerns about the development of sound impeachment law. But at times Ackerman seemed to be arguing that the Constitution required the Senate to refuse to proceed in the absence of impeachment charges made by the newly elected House members. ${ }^{67}$ Such an argument would indeed put in place a requirement that the House and Senate of a single Congress concur in a single impeachment and trial process. ${ }^{68}$ Ackerman's argument, if taken to support a constitutional imperative, would be vulnerable to the same criticisms that I have made regarding Isenbergh's proposal, based on the clear historical record allowing "holdover impeachments," voted before an election, to be tried in a subsequent Congress. ${ }^{69}$

67. See Impeachment Inquiry: William Jefferson Clinton, President of the United States; Presentation on Behalf of the President: Hearing Before the House Comm. on the Judiciary, 105th Cong. 37-46 (1998) (statement of Bruce Ackerman, Professor, Yale Law School). This misunderstanding of Ackerman's argument may have been fueled by the fact that he initially presented it as testimony to the House Committee on the Judiciary prior to that committee's vote on the articles of impeachment. Presenting his testimony to the House may have misdirected attention from the argument's real target, the Senate.

68. Posner sees Ackerman as making an argument "that the concurrence requirement for legislation ... should not be relaxed for impeachments." POSNER, supra note 23, at 128-29. To support this assertion, Posner cites pages 11 and 13 of The Case Against Lameduck Impeachment. ACKERMAN, supra note 55, at 11,13. I find nothing on page 13 referring, even indirectly, to a "concurrence requirement," whether for legislation or impeachment or anything else. Id. at 13. On page 11, Ackerman writes, "But is there an exception to this general [concurrence] rule for bills of impeachment? Many leading members of the Senate have been speaking as if the answer were obviously Yes. Some have even suggested that the Senate now has a constitutional obligation to begin the impeachment trial immediately upon the Senators' return to Washington in January." Id. at 11. Immediately after this, a new paragraph begins: "Nothing could be further from the truth." Id. Syntactically, this seems pretty clearly to reject the proposition that the Senators have an obligation to begin an impeachment trial. I suppose the passage can be read to support the proposition that Ackerman believes that there should be no exception to the concurrence requirement for bills of impeachment, but doing so seems to me inconsistent with the structure and logic of Ackerman's argument.

69. Posner predicates his criticisms of Ackerman's view as "unreasonable" on what I believe to be an understandable misunderstanding of Ackerman's argument. POSNER, supra note 23, at 128-29. Posner argues, for example, that Ackerman's position would make "void" impeachments voted by a House of Representatives prior to an election, not merely those voted in a lame-duck session. Id. at 129. (Friedman refers to such impeachments as hold-over impeachments.) This overlooks the role the Twentieth Amendment plays in Ackerman's argument. A hold-over impeachment might suffer some reduction in legitimacy, but not as great as occurs, on Ackerman's argument, with a lame-duck impeachment, given the specific focus of the Twentieth 
I believe there is a difference between constitutional law in this setting, which imposes legally binding requirements, and the law of impeachment, which suggests politically sound decisionmaking procedures. The difference is measured, in my view, by the larger role that prudence and political judgment play in developing the law of impeachment. Ackerman weakened his argument by sometimes presenting it as one concerning constitutional imperatives.

Finally, Ackerman's argument resembled Isenbergh's in that it was simply too fancy. Here, part of the difficulty arose from Ackerman's position in the legal academy and from his rhetoric. He is known well and sometimes disparaged as clever and thoughtprovoking but also as a scholar whose views, on reflection, seem unacceptable to many others. ${ }^{70}$ Further, he presented his argument in highly dramatic terms, a style that clearly has helped gain prominence for his views in the legal academy but that apparently plays less well in the political arena. ${ }^{71}$ The Senate gave Ackerman's proposal less attention than it should have, but its failure to do so in this instance is understandable and, to some degree, excusable.

\section{The Standard of Proof in Impeachment}

House members had to decide not only what constituted an impeachable offense, but also what standard of proof they should require once they had settled on a definition. As the issue came to be framed in the House, two standards of proof (roughly speaking) were available. The first focused on facts alone, and was referred to as the "grand jury" standard: did the factual evidence provide a reasonable basis (probable cause) for concluding that the President had commit-

Amendment on the particular problems associated with actions by lame-duck Congresses. It may be, as Posner argues, that the Twentieth Amendment cannot support the conclusions Ackerman draws from it. That, however, is different from saying that the logic of Ackerman's argument, including his reliance on the Twentieth Amendment, commits him to a criticism of holdover impeachments identical to his criticism of lame-duck ones.

70. For a suggestive comment, see Paulsen, supra note 59, at 1 ("I've always been envious of Yale Law School Professor Bruce Ackerman: He's brilliant, creative and clever."). The tone of Paulsen's article conveys more than any individual quotation could, however. For additional comments on Ackerman's rhetorical style (regarding a co-authored work), see Jeffrey S. Lehman \& Deborah C. Malamud, Saying No to Stakeholding, 98 MicH. L. REV. 1482, 1497-500 (2000) (book review) (criticizing Ackerman and his co-author for using rhetorical devices that are "so distracting that it becomes difficult to engage the substance of their proposals").

71. Ackerman's account of the Twentieth Amendment's adoption was particularly feverish. See Ackerman, supra note 55, at 17-32. 
ted an impeachable offense ${ }^{72}$ Some House members were attracted to the grand-jury standard, because they drew an analogy between the House-which, in impeaching, acted like a grand jury preferring charges - and the Senate, which, in trying an impeachment, acted as a trial jury. ${ }^{73}$

The second standard of proof incorporated a normative conclusion: given what a majority of House members concluded the President did, would the President's action justify removing him from office? This second standard would build into the House action some of the judgments senators charged with the ultimate decision to convict would have to make. Applying the second standard, a House member would ask, "Should a senator, convinced to the degree that I am convinced of the President's commission of the acts charged, vote to convict and thereby remove the President from office?"

The grand-jury analogy supported the grand-jury standard ${ }^{74}$ but, in my judgment, that standard was probably outside the range of reasonable interpretations. ${ }^{75}$ One may criticize the House as an institution for failing to conduct a focused debate on the standard of proof even if the grand-jury standard was a reasonable one. Of course each House member could decide independently what standard of proof should be required. But a process that allowed members to think clearly about the question was clearly desirable and did not take place.

The issue of standard of proof was obscured, because it was easy to frame the issue as dealing solely with the standard of proof of facts, rather than as one implicating a political judgment about the ultimate decision on whether the President should be removed from office. ${ }^{76}$ The House had a massive submission of facts from the Independent Counsel. It would have been ridiculous to plow the same ground again and, upon analysis, a factual inquiry was unlikely to alter a rea-

72. The Consequences of Perjury and Related Crimes: Hearing Before the House Comm. on the Judiciary, 105th Cong. 14-15 (1998) (statement of Rep. Gekas).

73. Id. at 133-34 (statement of Rep. Bryant).

74. For quotations from House members invoking the grand-jury standard, see David E. Kendall, Constitutional Vandalism, 30 N.M. L. REV. 155, 167-68 (2000).

75. Accord PosNeR, supra note 23, at 120 ("[B]ecause the trial of a President before the Senate is such a costly and disruptive process, it seems clear that the House ought to believe that the President is guilty, not merely that he may be, before it votes to impeach ....").

76. For statements showing how the question of the standard of proof was bound together with questions about whether the House should engage in a factual inquiry, see Kendall, supra note 74 , at 168 . 
sonable person's conclusions from the Independent Counsel's submission. The facts supporting the central charges could not be challenged reasonably. ${ }^{77}$ For those House members who thought that the standard of proof involved only the application of a standard to factual matters, it was reasonable to conclude that the grand-jury standard-and, indeed, many standards more demanding than probable cause-was satisfied, given the factual record before the House. That is, the problem was not that the grand-jury standard was correct or incorrect. Rather, the question was framed badly to the extent that it focused on facts alone and ignored the issue of the President's removal. Impeachment was designed to be a political process. It seems unreasonable to structure that process to render the House of Representatives, the body closest to the people, merely the processor of facts. The impeachment process should have clearly induced House members to exercise a political judgment, not simply a factual one, about whether the President committed acts that justified removing him from office.

Here, I think Congress can be faulted for failing to frame the issue clearly. The Independent Counsel's factual presentation made it too easy for the House to focus on facts rather than political judgment. ${ }^{78}$ And, of course, politics played a role here as it did in other aspects of the impeachment. Some House members found it politically desirable to obscure the question of removal. ${ }^{79}$ The interaction of politics and the Independent Counsel's factual submission led the House to act in a insufficiently responsible manner.

\section{An Overall Assessment}

The Clinton impeachment satisfies most of the relevant criteria for evaluating congressional constitutional interpretation. There was

77. Important elements of some charges rested on the resolution of conflicts in testimony by some witnesses. Without going into detail, I simply assert my conclusion that the witnesses providing the evidence supporting the charges were rather clearly more credible than those providing evidence that would undermine the charges.

78. Some opponents of impeachment tried to insert political judgment into the process by arguing that a prosecutor convinced of a person's guilt might nonetheless exercise discretion in refusing to charge the person. See supra note 39 and accompanying text. This argument did not make much headway, in part because it was connected to arguments that still rested on factual matters; in this instance, whether a prosecutor exercising discretion should take into account the prospect that a trial would result in an acquittal.

79. Among these members were those who, after voting in favor of the articles of impeachment, then stated publicly that they did not want the Senate to convict the President. See POSNER, supra note 23, at 120. 
no chance that the prospect of judicial review would distort Congress's actions and, of course, the impeachment and acquittal were completed actions. The episodes examined here involved matters about which the range of reasonable disagreement was narrow. However, "[g]reat cases like hard cases make bad law," the impeachment seemed like a great case. Therefore, Congress's performance under heightened political tensions may have been worse than would be true under more usual circumstances. ${ }^{81}$ Overall, though, Congress did not perform badly during the impeachment. ${ }^{82}$ Isenbergh's proposal was correctly rejected. To the extent that it failed to grapple with Ackerman's argument, the Senate did not perform as well as it otherwise might have. Moreover, the House should have come to a clearer conclusion about the validity of the grand-jury standard as the basis for impeaching a President. Congress's underperformance is understandable, however, and does not, in my view, seriously undermine the claim that Congress can do a decent job of constitutional interpretation. Recall that decency is necessarily a comparative standard and one that, according to academics, the Supreme Court routinely fails to rise to as well.

\section{THE WAR POWERS PROBLEM}

\section{A. Why the War Powers Problem May Be a Good Case Study}

Controversies concerning the constitutional allocation of the power to make war between Congress and the President come close to satisfying the criteria for evaluation of congressional constitutional interpretation. ${ }^{83}$ In addition, war-powers controversies have been common enough that they are almost routine. Although military commitments that put U.S. soldiers' lives at risk are clearly matters of great moment to members of Congress, I believe that such commitments are probably not perceived by those members as the kinds of

80. Northern Sec. Co. v. United States, 193 U.S. 197, 400 (1904) (Holmes, J., dissenting).

81. The 2000 election shows that the heightened political tensions associated with the impeachment may not be as extraordinary as they seemed at the time.

82. Kendall offers a different evaluation, though of course from the partisan viewpoint of an attorney representing President Clinton. See Kendall, supra note 74, at 155 (charging that the House's institutional performance throughout the impeachment proceedings was "so abysmal as to amount to constitutional vandalism").

83. See supra notes 5-39 and accompanying text. 
great cases that might make bad law. There are some important qualifications that complicate the picture, however.

The first is the ambiguous status of the judicial overhang. Since the enactment of the War Powers Resolution, members of Congress regularly have sought judicial review of presidential decisions regarding the deployment of military force overseas. ${ }^{84}$ The Supreme Court has never ruled directly on the standing issue raised in these cases. The Court of Appeals for the District of Columbia Circuit, where nearly all of these lawsuits have been heard, has developed a law of standing that first holds out the hope that someday some legislator will be found to have standing and then routinely denies standing in the court's exercise of equitable discretion. ${ }^{85}$ The ambiguities generated by this law mean that members of Congress might think that they have judicial review available to them. This mistaken belief might distort the way in which members consider war-powers questions.

Second, there is a wide range of reasonable interpretations of the Constitution's allocation of power in this area. Some scholars take the view that Congress has the primary role in committing U.S. armed forces to relatively large-scale operations in which they might meet armed resistance. ${ }^{86}$ Others contend that the President has the primary

84. For a comprehensive review, see generally Anthony Clark Arend \& Catherine B. Lotrionte, Congress Goes to Court: The Past, Present, and Future of Legislator Standing (unpublished manuscript, on file with the Duke Law Journal).

85. E.g., Campbell v. Clinton, 203 F.3d 19, 23 (D.C. Cir. 2000) (holding that a group of congressmen lacked standing to challenge the President's failure to abide by the War Powers Act in his deployment of U.S. forces to the former Yugoslavia because they had failed to exhaust their legislative remedies). For a survey of the cases and commentary, see Arend \& Lotrionte, supra note 84.

86. E.g., John HART Ely, WAR AND ResponsibiLity: Constitutional Lessons of VIETNAM AND ITS AFTERMATH 5-10 (1993) (rejecting the notion that the Constitution's requirements for the authorization of the use of force abroad have become obsolete or have been amended by subsequent practice); LOUIS FISHER, CONGRESSIONAL ABDICATION ON WAR AND SPENDING 183 (2000) (asserting that "it is not only unconstitutional but unwise to allow presidents to engage the country in war singlehandedly"); Louis Fisher, Congressional Abdication: War and Spending Powers, 43 ST. LouIS U. L.J. 931, 1006 (1999) (calling for joint action by Congress and the President on war-powers issues and suggesting that unilateral actions by the President are "inherently unstable"). I emphasize that the concept of abdication comes into play only when one believes that the Constitution specifies some particular allocation of power between the President and Congress. E.g., FISHER, supra, at xiv ("Abdication means to relinquish a right or power.... Abdication means giving to someone else something that belongs to you."); Douglas R. Williams, Demonstrating and Explaining Congressional Abdication: Why Does Congress Abdicate Power?, 43 ST. LouIS U. L.J. 1013, 1014 (1999) (noting that Fisher's position requires "the elaboration of a constitutional theory of war powers .... [that] would establish the constitutional baseline"). 
power to initiate such operations, subject only to subsequent congressional control through the appropriations process. ${ }^{87}$ It might be difficult to locate any completed congressional action inconsistent with some position within this reasonable range. A further complication is that one view, probably also a reasonable one, holds that the Constitution does not specify an allocation of power between Congress and the President and that the allocation of power depends solely on political interactions between the branches. ${ }^{88}$ It is important, I believe, to distinguish this position from others that find, in the accumulated weight of practice, criteria for determining the proper allocation of power between Congress and the President. ${ }^{89}$ The latter position holds that, at any given time, the accumulated weight of practice determines the proper allocation of authority. It acknowledges that practice can change incrementally, leading to the conclusion that different allocations may be constitutionally commanded at different times. The former position, in contrast, is that there never is a constitutionally mandated allocation of authority, except in the sense that the Constitution creates a framework within which President and Congress contend for power; not one determined by text, nor one determined by practice, but only by the outcome of political struggles over that allocation at particular moments in time. Not surprisingly, lawyers are uncomfortable with a position that finds nothing in the Constitution other than politics to determine so important a matter, and it is accordingly difficult to locate lawyers or legal academics making strong statements of this position.

87. E.g., John C. Yoo, The Continuation of Politics by Other Means: The Original Understanding of War Powers, 84 CAL. L. REV. 167, 174 (1996) (insisting that the Constitution was "designed to encourage presidential initiative in war" and that Congress can "express its opposition to executive war decisions only by exercising its powers over funding and impeachment").

88. E.g., Williams, supra note 86 , at 1018 :

I shall simply assume that throughout our nation's history, there has never been a relatively stable and widely accepted understanding of constitutional war powers, leaving the matter more or less up for grabs. ... [The] baseline [is] . . . one from which no conclusive showing can be made for saying that either Congress or the President is vested with exclusive authority over particular aspects of war.

The difference between this last position and the others may be illustrated in this way: According to the second view, in which Congress has the power to control presidential action after the fact through the appropriations process, congressional efforts to affect war-making decisions before the fact, through requirements that Congress be notified or give its consent in advance of action, are unconstitutional. According to the third view, the Constitution permits such beforethe-fact actions if Congress has sufficient political power to get away with them.

89. E.g., Peter J. Spiro, War Powers and the Sirens of Formalism, 68 N.Y.U. L. REV. 1338, 1355-65 (1993) (reviewing JOHN HART ELY, WAR AND RESPONSIBILITY: CONSTITUTIONAL LESSONS OF VIETNAM AND ITS AFTERMATH (1993)). 
Perhaps these difficulties can be avoided, however. Sometimes critics charge Congress with irresponsibility in exercising the war powers it has. ${ }^{90}$ In the most general terms, the charge is that Congress fails to take any position regarding the allocation of war-making authority between it and the President. By doing so, critics assert, Congress positions itself to criticize the President if the military operation fails and to claim credit if the operation succeeds. ${ }^{91}$

\section{B. The Kosovo Episode}

Congress's action in connection with the 1999 military operation in Kosovo provides an opportunity to assess this criticism and thereby to see how well Congress performed as a constitutional interpreter. The military operation began on March 24. On the previous day, the Senate, by a vote of 58-41, adopted a concurrent resolution authorizing the President "to conduct military air operations and missile strikes" against Yugoslavia. Almost a month later, the House rejected the concurrent resolution by a tie vote of 213-213. On the same day, the House rejected a declaration of war against Yugoslavia by the overwhelming margin of 2 in favor, 427 against. It also rejected a concurrent resolution directing the President to remove troops from Yugoslavia, by a vote of 139 in favor and 290 against. The House did adopt a bill prohibiting the use of ground forces in Yugoslavia, but the bill did not come up for a vote in the Senate. Finally, Congress approved an emergency supplemental appropriations bill to cover the Kosovo operation's costs. ${ }^{92}$

Congress's failure to adopt a clear position on the Kosovo operation might seem to exemplify irresponsibility. As Louis Fisher notes, the House took "multiple and supposedly conflicting votes" and "the Senate decided to duck the issue." ${ }^{, 3}$ And yet, the example is not as clear as one might hope. First, as the title of a classic political science

90. E.g., Abraham D. Sofaer, The Power Over War, 50 U. MiAmI L. REV. 33, 55 (1995) ("Why is Ely not shocked at the irresponsibility of setting out, in advance and in a statute, the very untenable and scornworthy defense that legislators advanced during Vietnam: 'We approved and paid for it, but it's not our war?'"); Daniel N. Hoffman, A Republic, If You Can Keep It, 82 Mich. L. Rev. 997, 1001 (1984) (reviewing EDWARD KEYNES, UndeCLARED WAR: TWiLight ZONE OF CONSTITUTIONAL POWER (1992)) (referring to the phenomenon of "a Congress reluctant to challenge presidential initiatives for fear of being branded subversive, appeasing, or otherwise irresponsible").

91. For a collection of quotations to this effect, see Williams, supra note 86, at 1036-37.

92. FISHER, supra note 86, at 100-04 (describing these congressional actions).

93. Id. at 102. 
article puts it, "Congress is a 'They,' not an 'It.","94 That is, every single member of Congress might have a fully formed and defensible position on the allocation of war power between President and Congress, and, even so, the aggregation of those positions in a majority voting system might produce an outcome in which Congress as an institution takes no clear position on that allocation..$^{95}$ Note, for example, that a clear Senate majority took the position that Congress ought to endorse the military operation, as did exactly half of those voting in the House. ${ }^{96}$ Those opposing the military operation had reasons for their opposition, as well. In the aggregate, "Congress" might be said to have abdicated its institutional responsibility to take a clear position on the constitutional question, but no individual member of Congress will have done so. In this way, the requirement of evaluating only completed actions makes it difficult to assess Congress's actions: each completed action, in each house, might be constitutionally responsible, ${ }^{97}$ but the series of actions taken together supports the charge of irresponsibility.

Beyond this, there is a bit more to be said. First, as noted above, one of the contending views of the allocation of the war power is that Congress's only role comes when it exercises its power to appropriate funds. Congress, as an institution, played that role-and perhaps only that role-in connection with the Kosovo operation. In that sense, Congress did adopt a position within the range of reasonable options available on the question of the allocation of the war power. ${ }^{98}$

Second, as noted earlier, perhaps the Constitution says nothing about the allocation of war power between the President and Congress, leaving to the branches the political process in which to work out differences. If so, the notion of congressional irresponsibility is inapt: Congress will do what it does and the President will respond, in

94. Kenneth A. Shepsle, Congress is a "They," Not an "It": Legislative Intent as Oxymoron, 12 INT'L REV. L. \& ECON. 239 (1992).

95. This differs from the argument discussed earlier, supra notes 74-76, that Congress did not focus clearly enough on the standard of proof in impeachment, because here the congressional deliberations provided the focus for the discussion. As noted earlier, the most one can ask for is such a focus, not a clear resolution binding each member of Congress.

96. The conclusion I seek to draw here may be obscured by the possibility that some members of Congress believed that the military intervention was a good idea but that Congress had no constitutional duty to endorse such an operation. These members could vote in favor of the operation without committing themselves to a view on the underlying constitutional question.

97. I put aside as analytically uninteresting the anomaly of the exact split in the House.

98. Obviously, a refusal to appropriate funds would also, on this view, have been a constitutionally responsible decision. 
part perhaps, by charging Congress with irresponsibility. As the controversy proceeds, some accommodation will be worked out, or one side will prevail entirely. And that, according to the "political process" option, is all that the Constitution requires. ${ }^{99}$

Finally, and relatedly, I am unsure about the cogency of the charge of irresponsibility. War-powers decisions can be highly contested, and people can reasonably differ about the wisdom of any particular operation. What to one observer seems irresponsible might be characterized by another as an appropriate ambivalence about the proper course to pursue in a situation of ambiguity. Further, precisely to the extent that the critical observer can charge Congress with irresponsibility, so can constituents. The charge is that members of Congress may be trying to have their cake and eat it too, by taking positions that allow them to criticize an unsuccessful military operation and claim credit for a successful one. That is, irresponsibility can be politically beneficial. But constituents can notice the member of Congress's course of conduct just as readily as can the critic. Constituents can punish their representatives for perceived irresponsibility, thereby eliminating the purported political benefits of such behavior. To the extent that Congress behaves irresponsibly, its members may lose the electoral benefits thought to flow from irresponsibility. ${ }^{100}$ That, in turn, increases the likelihood that Congress acts responsibly.

I believe that the pattern Congress's response to the Kosovo military operation exhibits is typical: charges of congressional irresponsibility or abdication are made but, upon analysis, these charges turn out to be less cogent than initial reaction to Congress's actions suggests. On the whole, we can understand the actions of individual members of Congress as clear commitments on contested constitutional questions that are within the range of reasonable answers, and we can understand what Congress as an entity did to be consistent

99. But see Williams, supra note 86 , at 1030 (arguing that the constitutional allocation of authority requires that Congress "politicize the question of constitutional war powers"). I believe that even if this is an accurate characterization of the general approach's requirements (rather than of Williams's own version of the approach), Congress necessarily politicizes the war-powers question by acting in whatever way it chooses.

100. See id. at 1039-40 (noting the "unanswered ... question of why legislators would think their electoral prospects are enhanced by abdication"). Williams supplies an answer through a collective-choice explanation, according to which the benefits of non-abdication are distributed widely among all members of Congress, while higher costs are borne by individual members of Congress. 
with at least two (and perhaps more) reasonable interpretations of the Constitution's allocation of power between the President and Congress.

\section{CONCLUSION: ACCOUNTING FOR CONGRESSIONAL CONSTITUTIONAL RESPONSIBILITY}

The informal case studies I have presented suggest that Congress can be, and frequently has been, a responsible interpreter of the Constitution. I suspect that the sense of congressional irresponsibility expressed by many commentators arises from a failure to examine cases selected on the basis of suitable criteria. Specifically, I believe that in cases involving individual liberties, the judicial overhang may reduce the incentives that members of Congress have to act responsibly.

Like the courts, Congress operates under incentives particular to the institution and within a specific institutional structure. Some commentators assert that for courts, the institutional context inclines the judiciary to provide reasonable constitutional interpretations. The same assertion may hold for Congress as well. I conclude by sketching what those structures and incentives might be.

First, members of Congress usually want to be reelected. To win reelection, they must satisfy their constituents' desires. Those desires have two components. First, there are the usual interests that we typically label "special interests": the desires of constituents who make a living farming regarding agriculture policy, the desires of constituents who are union members regarding labor policy, and the like. A member of Congress who satisfies enough constituent interests of this sort has some freedom to pursue other goals, including advancing the member's vision of the Constitution to the extent that this vision does not conflict with constituents' other interests. Second, constituents themselves may have constitutional visions and, more important, may think it valuable for their representatives to be independent constitutional thinkers-independent, that is, of constituents' special interests and constitutional visions. ${ }^{101}$ Taken together, these components of constituent interests make it possible for some members of Congress to vote their constitutional consciences without endangering their

101. For development of the argument that constituents may value constitutional responsibility, see TUSHNET, supra note 15, at 107-08 (describing the "value-based" incentives representatives have to act in a constitutionally responsible manner). 
electoral prospects. Sometimes, such voting behavior may even enhance those prospects. ${ }^{102}$

Turning from the constituencies to Congress itself, the most important structural feature is complexity. ${ }^{103}$ Political scientists have noted the existence of numerous veto points in the legislative process. $^{104}$ That is, for Congress to take what I have called a completed action, many individual members of Congress, acting on their own rather than through some version of majority rule, must decline to exercise a power to halt the action's advance. With many veto points and some members of Congress free to act on their sense of constitutional responsibility, completed actions may frequently be constitutionally responsible as well. ${ }^{105}$

Congress will not always act in a constitutionally reasonable manner, no matter how wide the range of reasonableness is. But, then, neither will courts. Taking everything into account, we have little reason to think that Congress will be systematically worse than the courts in interpreting the Constitution, at least when acting free of the judicial overhang.

102. This does not ensure that these members will advance constitutionally reasonable positions. My argument is only that under some conditions some members of Congress are in a position to think about constitutional matters independent of the "special interest" pressures asserted by their constituencies.

103. Here I deal only with existing structures of congressional decisionmaking. Congress's decisionmaking capacity might be improved by the creation of committees charged with the responsibility for determining whether proposed legislation was consistent with the Constitution. It is not clear to me, however, how such committees would operate-whether, for example, a rule allowing a point of order against considering any proposal that had not been vetted by such a committee would be followed, routinely overridden, or even ignored. Nor is it clear which members of Congress would find it politically attractive to serve on such a committee.

104. E.g., Gary W. Cox \& Mathew D. McCubbins, Legislative Leviathan: Party GOVERNMENT IN THE HOUSE 256 (1996) (documenting uses of this veto power in the committee agenda-setting process); McNollgast, Positive Canons: The Role of Legislative Bargains in Statutory Interpretation, 80 GEO. L.J. 705, 707-08 (1992) (referring to a "sequence of veto points through which a statute must pass").

105. Note that this conclusion would hold even if some members of Congress were irresponsible. (I am reasonably sure that a political scientist trained in positive political theory could develop a model that formalized the argument I have made in the text.) Note as well the argument that veto points obstruct constitutional responsibility with respect to whatever positive duties legislatures have under the Constitution. That is, the possibility that vetoes may be exercised at many points reduces the probability that Congress will enact any legislation and reducing the probability of enactment raises constitutional questions with respect to duties Congress might have to enact particular laws. 